\title{
Dichotomy of Declarative and Real Regional Politics in Modern Russia
}

\author{
Leonid E. Kozlov ${ }^{1} \&$ Andrei B. Volynchuk ${ }^{2}$ \\ ${ }^{1}$ Far Eastern Federal University, Vladivostok, Russia \\ ${ }^{2}$ Institute of History, Archeology and Ethnography of the Peoples of the Far East, the Far Eastern Branch of the \\ Russian Academy of Science, Vladivostok, Russia \\ Correspondence: Leonid E. Kozlov, Far Eastern Federal University, Vladivostok, Russia. E-mail: info@ores.su
}

Received: June 9, $2019 \quad$ Accepted: August 25, $2019 \quad$ Online Published: August 31, 2019

doi:10.5539/jpl.v12n5p118 URL: https://doi.org/10.5539/jpl.v12n5p118

\begin{abstract}
The main subject of consideration in this article is the problem of regional policy implementation in modern Russia, which is studied on the example of the Russian Far East. The Russian experience of regional politics clearly traces the dichotomy of declarative and real regional politics. The dualism of declarative goals reflected in the public documents of regional policy and real goals naturally leads to the discrepancy between the planned and real results of regional policy. The causes and results of this phenomenon are analyzed in this article. The authors proceed from the fact that there may exist a course hidden from the public, which is not formalized in public documents and does not directly correlate with the acute problems of peripheral region development in any country actively pursuing regional policy. This approach can be applied to any large country where there is a noticeable difference between the goals and results of regional policy.
\end{abstract}

Keywords: regional policy, core-periphery relations, spatial development, regional election, technocracism, Russian Far East

\section{Introduction}

Observing the socio-economic development of the East of Russia and the relations between the center and the regions for many years, we thought why the scientific literature - primarily on spatial economy and socio-economic geography - constantly criticizes Moscow regional policy for its low efficiency. We also noticed that researchers take official strategies, laws, and statistical materials as an empirical basis.

We assume that there may be a course hidden from the public, which the government adheres to and which is not formalized in public documents, in the same way as it often happens in foreign or domestic policy in any country actively pursuing regional policy. It seems to us that the socio-economic tasks, the tasks of internal stability and security, and the rent-oriented behavior of officials form a single conglomeration of factors that any targeted actions of the center in relation to the regions are included in the general system of a certain regional metapolitics. In this article, we test how the dichotomy of declarative and real regional politics works in modern Russia.

Mostly we observe processes to the east of Lake Baikal, however, the processes described are fundamentally similar in all parts of Russia. Chronologically, we focus on 2014-2019.

To solve the main problem, we answer the following questions:

- What are the ways to diagnose the presence of this dichotomy?

- How does this affect the methodological tools of regional policy?

- How does this affect the effectiveness of regional policy?

\section{Methods}

The methodological basis of our article is, first of all, the theory of the center and the periphery in the classic version by John Friedmann, which contains the following definition: "The periphery is defined by its relation of dependency to the core. Core and periphery together constitute a complete spatial system or subsystem. A spatial system is integrated through a pattern of authority-dependency relationships that is focused on the dominant core 
regions". Secondly, this is the theory of Illiberal Democracy of Fareed Zakaria, which indicates the widespread use of political regimes in the modern world that skillfully imitate democratic norms and procedures, but actually deprive their citizens of the opportunity to influence on power and political decisions. Thirdly, this is the theory of rent seeking behavior of Gordon Tullock, which explains the personal material interest of policy decision makers.

We understand the regional policy as a set of methods, legislative and other regulatory legal acts, development plans and programs developed and implemented by the competent state authorities, with an aim of forming a given territorial structure of the economy and society.

Our main empirical sources are as follows:

1) Federal target programs, regional and sectoral development strategies of Russia;

2) Statistical collections of the Russian Statistic Service (Rosstat) on the socio-economic results of the regions;

3) Statistical collections of the Central Election Commission, in particular, the results of the regional elections of 2018.

4) The sites of state programs for political manager recruiting;

5) Long-term personal observations of the political process in the Far East, including the elections to government bodies, rallies and demonstrations, political and economic forums, agitation and propaganda, etc.

\section{Literature Review}

Summarizing works on the regional policy of Russia are written mainly by Russian authors. This topic is always highly relevant for them, given the huge and extremely heterogeneous territory of Russia and the traditional low quality of state institutions. The magazine "Regional Studies of Russia" publishes the best articles in English which were published in Russian earlier.

Alexander Shvetsov notes the leading role of state power in the development and transformation of the socio-economic space of Russia. Nowadays, the Russian government today tries to revive the harsh Soviet governance of the regions, which does not correspond to the current situation. The government acts in the interests of lobbying groups to a greater extent than in the national interests. The author considers it more promising to improve the institutions of power and management methods at the municipal level. Vladimir Klistorin agrees with him, according to whom Russia is not a real federation because it does not have effective institutions for the participation of regions in the development of policy at the country level. Putin's domestic policy has led to the decrease of real political and financial capacities of the regions and municipalities and to the center role increase in the regional policy decision making.

On the contrary, Vyacheslav Seliverstov concludes that the political system and the federal structure of Russia are stable, the inter-budgetary relations are stable, the regional legislation is brought into line with federal legislation, although this is not easy to do in conditions of extreme inter-regional differences and modest budget allocations, as compared with macroeconomic and financial politics.

Olga Kuznetsova, using the example of Russia, has developed an original concept of regional development factors, similar to Maslow's hierarchy of needs. She believes that state policy and the quality of management are important, but not the main ones, less important than the objective factors, such as the place of a region in the general system of the country territorial organization, the type of development and the level of development of the region, economic and geographical location, natural conditions and resources, the composition of the population, the settlement system, the economy development level and characteristics.

Pavel Minakir studies the influence of space on the economic development of Russia. According to his observation, the spatial development strategy of Russia, as well as the strategies of individual regions, describe ideal regional economies that are not interconnected by hierarchical or cooperative ties, and the national economy acts like their mechanical aggregate. These strategies have turned into a bureaucratic routine and have little to do with reality.

Natalya Zubarevich emphasizes the leveling, stimulating and geopolitical priority of regional policy. Earlier, Russia fluctuated between the first and second vectors, but in the 2010-ies geopolitics began to dominate. The main efforts of Moscow are now aimed at security provision for some territories of international importance (the Far East, Crimea, Kaliningrad, the Caucasus). This is the costliest type of regional policy; moreover, state investment in these regions does not encourage private firms to do business there.

Nadir Kinossian analyzes Russia regional development planning in the context of its political authoritarianism 
and neoliberal economic policy. In his opinion, the Russian government cannot develop an integrated model of regional policy because of the fundamental contradictions between authoritarian centralization and the need to stimulate growth. The slogans of regional alignment and development of the periphery remain on the political agenda of Russia, however, economic rationality is still more important, therefore, the polarization of territorial development grows inevitably.

Andrei Starodubtsev considers the regional policy of Russia in the context of Putin's program of authoritarian modernization, aimed at socio-economic growth without full democratization. An extensive system of control over regional elites and their leaders, combining institutional, tax, investment elements, politically centralized, but administratively decentralized, was created during Putin's period. According to the author, the stimulation of regional development in Russia was not very successful due to the bureaucracy resistance, some pressure groups and senior officials who do not consider regional problems as a priority.

Helge Blakkisrud explores "Turn to the East" in the context of Russia overall regional policy. He notes that Moscow approach to the Far East management and reorientation of Russia to the relations with East Asian countries is based on the traditional principles of the post-Soviet bureaucracy, namely: the state is a leader in modernization and economic development, reforms should follow some strategic plan, preferably in the form of targeted programs. At that, this top-down approach often coexists with manual control, when senior officials are forced to participate in private regional problem solution.

Silvana Malle and Julian Cooper emphasize that defense strengthening and the East of Russia development have become Putin's top priorities. The authors note the extreme centralization of the regional policy of Russia. Without denying its creative possibilities, they consider such a centralized policy to be unnecessarily costly. In their opinion, the regional policy of Russia would be more effective if the center provided the regional authorities with more power during development project selection and benefit provision.

In contrast to top-down regional policy studies, Gulnaz Sharafutdinova and Rostislav Turovsky indicate that regional administrations, for their part, try to influence the distribution of state intergovernmental transfers. The authors emphasize the importance of the administrative potential and good relations of the regions with federal officials to attract additional transfers, which are sharply needed by the regional budgets.

Among the extensive literature about the influence of Moscow on regional political processes, we highlight the article by Regina Smyth and Rostislav Turovsky on the election of Russian governors in the 2010-ies. According to the authors, the Kremlin is trying to ensure the victory of the right candidates through auxiliary institutions, subnational punishment regimes, ballot construction, and turnout manipulation. At the same time, the Kremlin seeks to minimize the possibility of protest after the election. In general, the regional electoral system of Russia does not imply free will, but prevents elite conflicts within.

These conclusions are confirmed by Cameron Ross. His study shows that the Kremlin does not want to risk using direct fraud during the vote count, focused on opposition party and candidate registration prevention in regional elections. This strategy has led to the creation of boring and predictable contests and a sharp decrease in turnout, which undermines the real legitimacy of the power party for Russian society and jeopardizes the stability of the Putin regime in the long term.

\section{Results}

\subsection{The Declarative Part of the Regional Policy of Russia}

The Russian authorities pay great attention to the planning of national economic development, including the territorial aspect. The following documents have been adopted in this area, mainly at the level of the Russian government:

- The fundamentals of the state policy for regional development of Russia during the period until 2025 (approved by the decree of the President of Russia in 2017);

- The strategy of spatial development of Russia during the period until 2025 (2019);

- The strategies for socio-economic development of each federal district, as well as the Arctic, the first such strategy was developed for the Far East in 2009;

- The plans for the implementation of these strategies, as well as the Comprehensive plan for the modernization and expansion of the main infrastructure during the period until 2024 (2018);

- The targeted programs for the development of key regions, including the State program "Socio-economic development of the Far East and the Baikal region" (2014); 
- The development strategies for the most important sectors of the Russian economy, such as the mineral resource complex, transport, energy, which, according to the instructions of President Putin, necessarily include the Far Eastern part nowadays;

- The forecast of the long-term socio-economic development of Russia, its current version considers the scenarios of events until 2036, but the territorial aspect is presented in more detail by the previous version until 2030 (developed by the Ministry of Economy of Russia in 2013);

- The concept of border area development of the Far East and the Baikal region (2015).

Also, the main guidelines of regional policy are listed by the President of Russia in his annual address to the national parliament. The statements and interviews of senior government officials, the transcripts of the government meeting and the Security Council of Russia and other sources supplement the general idea about the official part of the regional policy of Russia, as well as the regulations establishing special tax and administrative conditions for economic activity in individual regions. More than 30 of such acts were adopted during 2009-2019 in relation to the East of Russia.

Despite the abundance of strategic, planning and regulatory documents, Russian experts are very critical about the management of territorial development of Russia. They indicate that many central and regional scientific and practical institutes worked in the USSR, which collected and systematized information on the territory of the country, its resources, and, under the guidance of the State Planning Committee, designed and brought into the common system the territorial development plans from the municipal to the state level. Nowadays, this design work is carried out by federal ministries, that is, officials, or private firms, which are selected mainly on the basis of the lowest price during government tenders. Russian experts believe that modern territorial development strategies are standard, formal, do not set specific goals and are a set of good wishes. However, we clearly see a request from the central government to systematize and rank spatial problems and the methods of their solution, to calculate available resources and formulate target indicators.

The regional policy of the center to the east of Lake Baikal is presented in the above documents as follows. First, the "geostrategic" significance of the Far East is necessarily emphasized for the development of Russia. The Far East provides communication between Russia and the Asia-Pacific countries. Thus, Russia receives an alternative vector of foreign economic relations to Europe. Russian foreign policy documents emphasize that East Asian countries (primarily China) are striving for a fair world order based on a balance of forces and interests, in contrast to the West, which puts constant pressure on Russia.

Secondly, the main socio-economic problems of the eastern part of Russia are poor transport, energy and communications infrastructure, focal settlement, negative demographic and migration trends, poor quality of housing and communal services and social institutions, low productivity and high labor intensity, weak economic ties with the western part of Russia and too much economic influence of foreign countries.

Thirdly, the main methods of this macro-region development are the modernization of the infrastructure of transport, energy, communications, housing and communal services, healthcare institutions, higher education and culture, subsidization of energy and transport tariffs, simplified and free allocation of land for business and housing, tax and administrative privileges in localized territories, reduction of customs and other barriers in economic relations with Asian countries. The protection of the environment and the support of indigenous peoples are mentioned briefly.

Fourth, public investment is largely dependent on the activity of local authorities and private business, in contrast to 2007-2014, when the federal budget was actually their only source. Russia economic and budgetary difficulties caused by the world market conditions and Western sanctions force Moscow to use the principles of public-private partnership more often, for example, when special economic zones are created for specific business projects.

It is easy to notice that these documents depict a certain idealized model of the national and regional economy. Recognizing the existence of problems, they do not say anything about their causes, in particular, about the huge pressure from the administrative and law enforcement agencies on small and medium-sized businesses, about excessive legal regulation of business, about the high criminalization of the commodity sector, about the merging of certain bureaucratic, law enforcement, entrepreneurial and criminal structures in political and economic clans, about corruption of the highest bureaucracy and the contractors of federal mega-projects, etc. These factors are common to all of Russia, but they are compounded in remote regions due to the range of distances and focal settlement, the center is less able to control local social processes. 


\subsection{Regional Development Results, Far from Target Indicators}

The socio-economic results of the regional policy are different during last years. The claimed improvement of the Far East regional economy and demography state and structure did not happen. Moreover, the possibility of the regional policy of Russia implementation continues to deteriorate amid the stagnation of the national economy, the reduction of budget revenues and the preservation of foreign sanctions against Russia.

All this despite the fact that the growth rate of the gross regional product (GRP) of the Far Eastern District has traditionally been slightly higher than in the country as a whole over the past year, $4.4 \%$ versus $3.2 \%$. The structure of gross value added created in the region demonstrates the steady dynamics of imbalance increase towards the mining industry. Over the past eight years, the share of mining industry has gradually increased from $24.3 \%$ in 2010 to $28.1 \%$ in 2018 . This process takes place against the background of the processing industry share preservation in the structure of GRP at the level of 5.4-5.8\% for that same time period. And this is taking into account the implementation of many federal and regional programs in the Far East to stimulate the socio-economic development of the region. One of the main goals, which is a qualitative change in the structure of the Far East GRP in favor of the economy sectors with high added value.

In January-September 2018, 798 billion rubles of investments in fixed assets were used to develop the economy and the social sphere of the Far East, or 104.6\% to the corresponding period level of the previous year. The share of investments at the expense of own funds amounted to $46.9 \%$, attracted funds $-53.1 \%$, including $4.6 \%$ from the federal budget. At the same time, there is the structural imbalance in the investment sphere: $33.8 \%$ of investments are in mining, and only $7.5 \%$ is in manufacturing. The remaining types of economic activity, which actually create the "quality of the territory", account for education $-3.5 \%$, agriculture $-3.1 \%$, construction $2.7 \%$, and health care $-2.7 \%$.

Thus, the population of the Russian Far East continues to decline. Negative trends are observed both in the natural (fertility/mortality) and in the mechanical (emigration/immigration) population movements within the region. So in general, the number of deaths $(12.0 \% 0)$ in the Far Eastern Federal District exceeded the number of births $(11.9 \% 0)$ by 833 people or $0.9 \%$. Despite the relatively young population of the region, whose number of people at the age of 15 years and older was 3.3 million people $(66.3 \%)$ by the end of 2018 , the negative dynamics of natural growth has persisted for several years. And if earlier the natural decline was compensated by the migratory inflow, now this compensatory mechanism is working in the opposite direction. According to the results of 2018, the migration outflow of the population amounted to -36.7 thousand people.

However, one cannot say that the regional economy is suffering from a shortage of labor. According to the Federal State Statistics Service, despite a significant outflow of the population, the unemployment rate in the Far East increased from $4.7 \%$ in 2018 to $6.1 \%$ during the first quarter of 2019. Perhaps this is due to the inclusion of Siberian subjects - the Trans-Baikal Territory and Buryatia in the Far Eastern District at the end of 2018, in which the unemployment rate is traditionally higher as compared to all-Russian indicators. However, this does not change the negative trend of the process.

Thus, in fact, there is an uncontrolled (or conscious?) conservation of the existing model of the economy, in which the population of the region is perceived to be excessive. According to preliminary estimates, 2-2.5 million inhabitants are enough for Moscow to ensure political control over the Far East, mining, transit function performance. At that, the level of the Russian armed forces deployed in the region is high enough to keep the territory under Russian sovereignty.

\subsection{Territorial Development and Electoral Manipulation}

Formally, the population of Russia can choose the governor of their region in competitive elections. In practice, however, the electoral process is under the strict control of the Russian presidential administration. A sophisticated system of opposition candidate deterrence has been developed. For example, each candidate must collect signatures from a significant number of deputies and mayors at the municipal level. The ruling party could not let any of the opposition pass through this filter, but in order to create the imitation of choice among the population, it provides support to candidates from obviously weak parties or weak "technical candidates" (or spoilers) from three other large parties that are represented in the national parliament. These three parties - the Communist Party, Liberal Democrats, Fair Russia - are oppositional only conditionally, since about $90 \%$ of their budget is state support.

Traditionally, the candidate from the power party is appointed by the acting governor and he can use the resources of state propaganda, and also show himself as an "effective manager for several months. He also receives an audience with Putin, who blesses him for governorship, as if transferring to him the part of his 
national leader charisma. In other words, all conditions are created in order to obtain a predetermined result with formal observance of the law. This mechanism did not fail during Putin's third presidency (2012-2018).

After Putin's expected election for the fourth term in spring 2018, he started an important, but extremely unpopular, pension reform. The retirement age was raised to 65 years for men and 60 years for women. According to the Federal State Statistics Service, 65 years is the average life expectancy of men in Russia. Many experts believe that this reform was the catalyst for the protest vote in the regional elections during the fall. However, we believe that general dissatisfaction has accumulated in respect of the economy decline, stingy social policies, the degradation of housing and communal services, the disparity of income between the center and the regions, the growth of corruption and street crime. Thus, in four regions, the candidates from the power party could not win either in the first or in the second round. The Kremlin took extraordinary measures to achieve the desired result there, although its protégés won in another 18 regions, that is, the thing was not about that the regions would go out of center control en masse.

The greatest resonance in Russian society and abroad was caused by the elections in the Primorsky Territory. In 2017, Andrei Tarasenko, a native of Vladivostok, who, however, worked for most of his life in St. Petersburg and Moscow, was appointed as acting governor. His election campaign was carried out according to the standard algorithm, the campaign was sluggish, not expecting resistance. Unexpectedly, in the first round, he could not get more than $50 \%$ of the votes which are needed to win. A little-known businessman Andrei Ishchenko, nominated by the Communists, took part in the second round. Between the first and the second round Putin met with Tarasenko personally and supported him. All local propaganda worked for the Kremlin candidate, while the opposition candidate could hold street meetings for voters, because all the owners of the halls refused to rent a hall for him. Despite this, the candidate from the Communists was ahead of the Kremlin candidate by $6 \%$ after the count of $95 \%$ of the ballots. However, election commissions re-entered the protocols with other results into the electronic database of the Central Election Commission at 19 precincts, and the Kremlin candidate suddenly won.

The official results of these elections caused widespread outrage both in the Primorsky Territory and throughout Russia. However, the Kremlin did not allow the recount of votes and simply canceled the election results. Although the chairman of the Central Election Commission Ella Pamfilova publicly called for an investigation, not one of the falsification participants was punished. During new election, the Kremlin nominated another candidate, an experienced politician and wealthy entrepreneur Oleg Kozhemyako. This time Andrei Ishchenko could not get through the municipal filter. According to official figures, the Kremlin candidate won. However, independent observers pointed to the abnormally high turnout and the percentage of votes for the Kremlin candidate in some precincts, as well as to the difference between election protocols and the standard form in the same precincts, which indicated falsification of the results by about $15-16 \%$.

In Khabarovsk, a candidate from the ruling party, who has led the region since 2009, entered the second round with the candidate from the Liberal Democrats. Unlike Vladivostok, this opposition representative was an experienced politician, the member of the national parliament and the owner of some successful enterprise. The Kremlin tried to stop the local protest by offering the Liberal Democrats the post of first deputy governor. They did not agree to this, however, did not actively campaign, and still they had a landslide victory in the second round: $70 \%$ against $28 \%$.

In the Vladimir region, the candidate from the power party, who has led the region since 2013, also entered the second round with the candidate from the Liberal Democrats. The difference from Khabarovsk was that the main opposition candidate from the Communists did not pass the municipal filter, and the candidate from the Liberal Democrats was an inconspicuous person. However, his victory in the second round was quite confident: $57 \%$ against 37\%. Independent observers noted the same strange mathematics in favor of the Kremlin candidate as in Primorye, but there were few abnormal precincts. The elections in Vladimir and Khabarovsk were held a week later than in Vladivostok, in connection with which independent observers suggested that the election organizers did not want to repeat the scandal and stopped the fraud.

In Khakassia, the situation developed in the most complex way. The candidate from the power party Viktor Zimin, who has ruled the region since 2009, scored only $32 \%$ in the first round. His main rival was a young man, a candidate from the Communists, who had almost no political experience and financial resources. And this was especially shameful for a power party candidate. The protests of the local population were so radical, and the winner was so unexpected that the Kremlin used an unconventional method to maintain control of the local political system: the candidate from the ruling party and all other candidates voluntarily withdrew from the elections. The Kremlin also urgently appointed another acting governor, more qualified than his predecessor. 
Thus, the Communist candidate needed to gain more than $50 \%$ in non-alternative elections, but he successfully coped with this task.

\subsection{The Success of Big Business in the East of Russia}

Against the background of the modest results of the cohesion policy and electoral discontent, large business primarily state and private corporations with the headquarters in Moscow - are optimistic about doing business in the East of Russia. We can judge this, in particular, by their investment programs.

Since 2007 Gazprom has been executing the Eastern Gas Program of the Ministry of Industry and Energy of the Russian Federation. Gazprom estimates the initial total gas resources of the East of Russia lands, from Irkutsk to Kamchatka at 52.4 trillion cubic meters, shelf resources - 14.9 trillion cubic meters. Among many other objects within the framework of this program the Sakhalin-Khabarovsk-Vladivostok gas pipeline was built in 2009-2011 with the capacity of 5.5 billion $\mathrm{m}^{3}$ of natural gas per year. It is designed primarily for gas export to East Asian countries. Currently, its capacity is expanding, and the LNG plant is also being designed in the Primorsky Territory. Mainly large consumers are connected among the local facilities, such as thermal power plants and industrial enterprises, the gasification of the residential sector is very sluggish. In 2014, Gazprom began construction of the Power of Siberia gas pipeline with the length of about $3,000 \mathrm{~km}$ and the capacity of 38 billion cubic meters of gas per year. The Amur gas processing plant being designed on its route will become the largest in Russia and one of the largest in the world. In 2007, experts estimated the total investment in the Eastern Gas Program at about $\$ 95$ billion until 2030. In conjunction with the Power of Siberia gas pipeline, the chemical company Sibur has developed the project for the Amur Gas Chemical Complex (about $\$ 8$ billion), the construction of which is planned for 2020-2024.

Rosneft oil company works on the project of the Eastern Petrochemical Complex (approximately $\$ 10$ billion) in the Primorsky Territory, which will produce gasoline, diesel fuel and other products. Its launch is planned in 2026-2029. Rosneft is producing oil on the Sakhalin shelf, exporting it, and also refining it at the Komsomolsk refinery. Rosneft and Gazprombank took control of the super-shipyard under construction in Primorsky Krai (\$ 0.4 billion), which will produce oil and gas tankers and repair warships, under the pretext of inefficient work of the first owner, the state-owned United Shipbuilding Corporation. The shipping company Sovcomflot is involved in this project as one of the main customers. It ordered seven oil tankers and gas carriers and plans to order seven more (the total sum makes $\$ 1.5$ billion approximately). Putin sets the goal to build such ships in Russia, although it would be cheaper and faster in South Korea and China. The main buyers of this oil and gas are the countries of East Asia and the USA.

Transneft transit company built the East Siberia - Pacific Ocean oil pipeline and the Kozmino port in the Primorsky Territory for about $\$ 25$ billion in 2006-2012. 31 million tons of oil and another 38 million tons are exported through Kozmino today, via the branch of this pipeline to China. First of all, oil was exported; two Far Eastern refineries were connected only a few years later.

Russian Railways invests about $\$ 1$ billion in the Far East annually for the modernization and expansion of railways and the acquisition of new locomotives. Russian Railways operates three crossings to China, and the cargo terminal in the border city of North Korea. In 2019-2020 they plan to complete the construction of a new bridge to China in the Jewish Autonomous Region. The main investment project of Russian Railways in the 2020-ies is the reconstruction of the Baikal-Amur Railway. The Far Eastern part of Russian Railways is filled with exported raw materials and is working to its limits in fact.

RusHydro Power Generator built and upgraded four large power plants in the Far East ( $\$ 1.4$ billion) during 2012-2018, and plans to modernize the other four power plants ( $\$ 3$ billion) in the coming years. Alrosa Diamond Mining Company invests more than $\$ 1$ billion in new diamond mines and diamond trading and cutting company in Vladivostok during 2016-2019. Siberian Coal Energy Company invested \$ 650 million in the new Vanino coal port within the Khabarovsk Territory, which began to operate in 2008. Over the next ten years, it invested about $\$ 0.8$ billion in coal production in the Far East, and plans to invest another $\$ 0.8$ billion to the extraction and transportation of local coal in 2018- 2023. Almost 60\% of its export supplies go to East Asia, primarily to Japan, China and South Korea.

During 2009-2021 the development company Crocus built the campus of the Far Eastern Federal University with a total area of 760 thousand square meters for $\$ 2.2$ billion in Vladivostok. This order was received by Crocus without competition, by the order of the Russian government. Another development company, Stroygazmontazh, similarly received the contract for the construction of a theater, educational and museum complex in Vladivostok for $\$ 0.5$ billion in 2019-2023. There will be the branches of the Mariinsky Theater, the Hermitage, the Tretyakov Gallery and the Bolshoi Theater. 
So, we see that the largest Russian companies have a great interest in their product export increase, mainly natural resources, to Asia-Pacific region. New export routes have been created actually, and even if the western branch of Russian exports is completely closed due to political tension between Russia and the West, Russia will be able to increase its export to the East relatively quickly. However, these new investors create new jobs not intended for the local population. Since the local population usually does not have the necessary competencies to work in new industries, it is easier for federal companies to bring ready-made workers from Central Russia than to train local residents.

\subsection{Political Recruiting and Rotation of Governors}

The reasons for the inefficiency of the Russian regional policy may be hidden both in its goal-setting and in the quality of the personnel potential of the regional administrative corps. In the first case, it is likely that an ineffective regional policy is the real goal of the federal government, its result should be the decrease of regional elite independence and the possibility of their competition with the Center for the access to regional resources. The task of control may be more important than the task of development for the Center. In this case, the Center spends more resources on maintaining the power pyramid than on regional development. Where the conflict between regional and federal elites has been overcome, the main resources can be directed to development. But most regions live in a situation of an inter-elite conflict. Moreover, the Center is not single, and not only and not so much federal actors are in conflict with regional actors, but different federal patrons support various regional clients. Another reason for the low efficiency of regional policy may be the inability to implement it, due to the poor quality of governance at all levels of government: federal, regional, and municipal.

The first assumption looks more dubious, since the sustainable socio-economic development of the regions, the level of population life quality on the ground are the condition for the country political system stability and the preservation of specific group power. Confirming this, the dynamics of the interests in the regions and the center demonstrate a gradual rapprochement of positions due to individual compromises and concessions. But the rapprochement of positions does not accelerate regional development automatically. The low level of managerial competencies, multiplied by rent-seeking behavior, does not allow the integration of the existing regional political elite into a new model of public administration, which should have the ability to adapt to the dynamic conditions of the modern world quickly.

Why the second assumption seems more likely:

- Regional political / business elites are updated extremely slowly;

- The modern regional elites were formed in the 1990-ies, when incompetent people often came to power, so the level of education and qualification of regional authorities may not correspond to the tasks set by the Kremlin;

- it is impossible to exclude the possible sabotage of regional elites conditioned by the reluctance of change;

- a clash of economic interests between regional political elites and federal economic "proxies" is clearly manifested in certain regions. Here we must proceed from the fact that any regional political elite is the economic elite of the region, however, not every regional business elite is a political elite.

The Kremlin sees the main reason for the difficulties of regional politics in regional elites and the professionalism of the managerial corps and dreams of a complete replacement of the political elite in the regions. The new elite must meet at least three requirements: 1) be devoted exclusively to the Federal Center, as the only source of its power and the condition of its political / physical existence; 2) not to be overgrown with economic assets and family ties in this region neither in the past nor in the future; 3) have the necessary level of qualification that meets the requirements of the Center. The main tool for managerial potential quality improvement was the new educational institution, the so-called School of young technocrats under the supervision of Sergei Kirienko, the deputy head of the presidential administration. If earlier the leaders of the Russian regions were the so-called effective managers, now they are being replaced by young cadres, who are called technocrats. Young technocrats in the Russian government are a new trend in the last three years.

Technocrats are usually qualified experts in the field of economics and management who are involved in specific managerial problem solution. In their work, they rely on scientific methods for managerial process organization. Daniel Bell defines their main feature as the administration of things and the replacement of politics by a system of rational decisions. According to the definition of McDonnell and Valbruzzi, an official can be classified as a technocrat if, at the time of his appointment, he never held public office as a representative of a political party, is not a member of any party, and has recognized abilities and experience in the field corresponding to his new responsibilities. It is assumed that technocrats will be able to transfer the process of optimal solution development to regional problems from the political plane into the practical one to bring the country and 
individual territories out of the economic or social crisis.

The Russian practice of a technocratic state apparatus development has national specifics. Russian technocrats of the 21st century have only one feature that can be considered consistent with the classical definition of the technocratic order: they are not accountable to the people, society, or party structures. The center relies on young politicians with federal experience and Moscow ties. Typically, these are proven managers from the economic sector, whose age does not exceed 45 years. Nowadays, they manage more than 30 of 89 constituent entities of the Russian Federation. It is assumed that young technocrats are not involved in regional politics entrusted to them, but restore the economy of problematic subjects of the country.

However, the preliminary results of technocracy are not straightforward. According to the St. Petersburg Politics foundation study, among 37 of the regions where the rotation took place, two-thirds of the regions became less stable. The socio-economic situation has improved with the advent of a new governor in 12 of 37 regions. In the remaining 24 regions, the index of socio-political stability declined. According to the fund, "the new practice of governor appointment does not bring down the system, but does not create any kind of large added value. It's like a pill for a headache: it relieves symptoms for a while, but does not solve the problem".

\section{Conclusion}

In our opinion, the regional policy of modern Russia clearly confirms that regional (and wider - territorial) policy is not reduced to socio-economic problems and methods. The socio-economic part of regional policy, usually presented in official strategies and programs, is implemented in an objectively existing political environment, combined with the tasks of political control, internal political stability and security. More precisely, in relation to the tasks of stability and security, socio-economic tasks occupy a subordinate position. The territory must be managed so that the territorial development plan can be implemented. In the case of Russia, either the territories are uncontrollable, if you let them conduct the elections honestly, or the Center thinks so and is afraid of independent regionals. In other words, either the problems are in the control unit, or the control object is too complex, and perhaps these problems exist simultaneously.

From an official point of view, regional policy is the policy of socio-economic development of the region, but in practice it is, first of all, ensures the control of the Center over regional resources and the loyalty of the local population. The second goals in Russia are achieved effectively. At the same time, the task of regional development is not canceled, the technocratic management is being educated, but this management is not supplied with political powers and has no political influence. In this case, the methods of regional policy are the manipulation of elections and election organization technology in general, personnel recruiting and the rotation of the highest regional bureaucracy. The problems of the real political process in the official political discourse are taboo, therefore they are ignored in the development of the declarative part of regional policy, and this is the underwater, the largest part of the corresponding iceberg. The regional policy of Russia is not ineffective, but external observers do not see it in its entirety.

The dualism of declarative goals reflected in public documents of regional policy and real goals, which we can only judge by indirect signs, naturally leads to the discrepancy between the planned and real results of regional policy, although, of course, the quality of program measure implementation should also be taken into account here. These indirect signs are a steady long-term significant deviation of regional policy results from program indicators, large national business as the main acquirer of development programs, the Center active influence on the political process in the regions, including the "cultivation" of regional leaders in the center. We believe that this analysis scheme is specific not only for Russia, but can be applied to any large country where there is a noticeable difference between the goals and the results of regional policy.

\section{Conflict of interest}

The authors confirm that the data presented does not contain any conflict of interest

\section{Acknowledgements}

The study was carried out with the financial support of the Russian Foundation for Basic Research in the framework of the scientific project No. 18-014-00012

\section{References}

Bell, D. (1976). The Coming of Post-Industrial Society: A Venture in Social Forecasting. Basic Books, p. 77.

Blakkisrud, H., \& Wilson Rowe, E. (2018). Russia's Turn to the East. Domestic Policymaking and Regional Cooperation. Palgrave Pivot, p. 167. https://doi.org/10.1007/978-3-319-69790-1

Friedmann, J. (1967). A general theory of polarized development. The Ford Foundation. Urban and regional 
advisory program in Chile, p. 78.

Golkar, M., Golkar, A., AbbasianKasgari, A., \& HosseiniToudeshki, E. (2014). Determining the Factors Influencing the Brand Equity from the Perspective of the Consumer in Iran Chocolate Industry (Baraka Chocolate). UCT Journal of Social Sciences and Humanities Research, 2(2), 47-57.

Inozemtsev V. (n.d.). We are not technocrats, not carpenters. Gazeta.ru. Retrieved May 10, 2016, from https://www.gazeta.ru/column/vladislav_inozemcev/10227899.shtml

Kinossian, N. (2013). Stuck in transition: Russian regional planning policy between spatial polarization and equalization. Eurasian Geography and Economics, 54(5-6), 611-629. https://doi.org/10.1080/15387216.2014.901176

Klistorin, V. (2014). Federal relationships, regional policy, and the problem of deformation of Russia's economic space. Regional Research of Russia, 4(4), 253-259.

Kuznetsova, E. (2018). The dependence of the parliamentary opposition on the budget reached its maximum. RBC. Retrieved from https://www.rbc.ru/politics/04/06/2019/5cf54b259a79476bebab250b

Kuznetsova, O. (2013). Regional policy of Russia: 20 years of reforms and new opportunities. M.: URSS.

Malle, S., \& Cooper, J. (2014). The pendulum moves from Europe to Asia. Modernizing Siberia and the Far East. Economic and security issues. Journal of Eurasian Studies, (5), 21-38. https://dx.doi.org/10.1016/j.euras.2013.10.004

McDonnell, D., \& Valbruzzi, M. (2014). Defining and classifying tech-nocrat-led and technocratic governments. European Journal of Political Research, 53(4), 657.

Minakir, P. (2016). National Spatial Development Strategy: Good Faith or Deliberate Simplification? (The National Strategy of Spatial Development: Is It the Conscientious Delusion or Deliberate Simplification?) Spatial Economics, (3), 7-15.

Minakir, P., \& Prokapalo, O. (2011). Programs and development strategies of the Russian Far East. The problems of the Far East, (5), 93-104.

Ross, C. (2018). Regional elections in Russia: instruments of authoritarian legitimacy or instability? Palgrave Communications, 4. http://dx.doi.org/10.1057/s41599-018-0137-1

Seliverstov, V. (2014). Federalism, regional growth, and regional science in post-Soviet Russia: Modernization or degradation? Regional Research of Russia, 4(4), 240-252.

Sharafutdinova, G., \& Turovsky R. (2017). The politics of federal transfers in Putin's Russia: regional competition, lobbying, and federal priorities. Post-Soviet Affairs, 33(2), 161-175. http://dx.doi.org/10.1080/1060586X.2016.1163826

Shiryaeva, K. (n.d.). Who are Putin's “young technocrats”? Regions. Retrieved from https://www.gosrf.ru/news/32421/

Shvetsov, A. (2015). Transformation of Socioeconomic Space: The Role of the State. Spatial Economics, (1), 38-61.

Shvetsov, A. (2018). Regional Policy Improvement. pp. 190-191.

Smyth, R., \& Turovsky, R. (2018). Legitimising Victories: Electoral Authoritarian Control in Russia's $\begin{array}{llll}\text { Gubernatorial } & \text { Elections. } & \text { Europe-Asia } & \text { Studies, }\end{array}$ https://doi.org/10.1080/09668136.2018.1436697

Starodubtsev, A. (2017). Federalism and Regional Policy in Contemporary Russia. Routledge, 188. https://doi.org/10.4324/9781315582061

The decree of the Russian Federation President No. 632 "On Amendments to the List of Federal Districts (03.11.2018), approved by Decree of the President of the Russian Federation No. 849 (May 13, 2000). Retrieved from http://publication.pravo.gov.ru/Document/View/0001201811040002

Tullock, G. (2005). Public Goods, Redistribution and Rent Seeking. Edward Elgar Publishers, p. 153. https://doi.org/10.4337/9781845424688

Zakaria, F. (2003). The Future of Freedom: Illiberal Democracy at Home and Abroad. W.W. Norton \& Company, p. 286.

Zubarevich, N. (2015). Geopolitical Priorities in Russia's Regional Policies. Opportunities and Risks. Russian 
Politics \& Law, 53(5-6), 44-62. https:// doi.org/10.1080/10611940.2015.1146060

\section{Copyrights}

Copyright for this article is retained by the author(s), with first publication rights granted to the journal.

This is an open-access article distributed under the terms and conditions of the Creative Commons Attribution license (http://creativecommons.org/licenses/by/4.0/). 